plant itself, which then bring about a reconstruction in the progeny in the direction indicated. Environment, therefore, is at once a selective and a formative factor; in these circumstances the formation of a species "as a rule embraces simultaneously many, frequently a very large number of individuals, which are then reformed under the influence of a changing environment or when the plant or a whole family is transferred to a different region"

During recent years Keller has been putting his ideas on the evolution of plants and his conceptions of the fundamental problems of ecology into practice in the Moscow Botanical Gardens of the Academy of Science of the U.S.S.R. which are being built in accordance with his plans.

Prof. Keller is a member of the Academy of Sciences of the U.S.S.R. and the Lenin Academy of Agriculture, director of the Moscow Botanical Gardens and president of the Turkmen Branch of the Academy of Sciences of the U.S.S.R. He takes an active part in public affairs and is a member of the Central Trade Union Council of the U.S.S.R. and of the Executive Committee of the Moscow Regional Soviet.

\section{SOCIAL RELATIONS OF SCIENCE*}

$7 \mathrm{HE}$ advent of peace has led to much discussion on the proper place of science in the post-war world. Different currents of opinion range from the extreme view of the need to suppress science on account of the dangers of its application to war, to that which considers that scientific activities need to be greatly increased and co-ordinated in the interests of providing better conditions of life in Great Britain and throughout the world. Not only is there no agreement as to the amount of science needed, but also considerable divergence of opinion on how science should be organized. Some think of science as "a proper oecupation for the leisure of an English gentleman", and consider that it is more important that it should be completely free and unorganized than that it should be adequately endowed; while others feel that the full value of science can only be reached if it is organized in relation to practical human activities of production, agriculture and health, and can draw on a far larger share of the national income than it has done hitherto. Those who hold the older views have never realized that the relation of science to society is not fixed but continually changes with the growth of science and the increase of complexity of society : what did well in ancient Greece or Victorian England is not appro. priate to the needs of to-day.

Science is not a simple thing; it eludes definition. It is at the same time a professional activity, a body of knowledge, a way of solving problems and an influence on the way in which everyone looks at the world and deals with it. Society is fully entitled to demand that science should be used in solving the problems of providing us with a better standard of living. It would be a very stupid society, however, that attempted to do this without considering the feelings and ideals of scientific workers and the unity of scientific knowledge, which is such that almost any part of it may turn out to bear on almost any other. The Nazis tried to do this : they discouraged fundamental science and generalized thinking and

* Substance of the Trueman Wood Lecture delivered by Prof. J. D. Bernal, F.R.S., before the Royal Society of Arts on May 16. thus, in spite of their enormous technical start, failed in war. Men of science who are taking the responsibilities of science seriously are well aware that a proper proportion of effort must be given to fundamental science which has no immediate application. Out of $£ 24$ millions, which the Association of Scientific Workers suggests should be budgeted for scientific research in Britain, more than $£ 2$ millions would go to fundamental science. The Association is also aware that the actual direction of scientific effort must be in the hands of scientific workers, who alone are competent to know what they are doing.

It is quite possible to plan science, as the example of Britain during the War and the Soviet Union before the War, have shown, in such a way that a continuous link is kept between applied science and fundamental science with a two-way flow of ideasof new ideas coming from fundamental science to be applied, and of problems coming from the applied field, leading to the production of new fundamental theories. The real danger to Great Britain is not that science will be over-organized, but that there will not be nearly enough of organized science. We spend only about one third as much, in proportion, and one tenth in total, as the United States and the Soviet Union on scientific research.

The immediate limiting factor is the number of scientific workers who will be available in the postwar years. With our present educational output, we can never produce scientific workers in adequate numbers; but the importance of this has not been realized, and the additional grants made to the Universities' Grants Committee will scarcely do more than make up for the increased cost of living.

Science is in this situation very largely because its wider influence has never been realized by the public. Science teaching is a belated and unwelcome part of the educational system, and the new Educa. tion Bill has not improved matters. Further, the Press generally treats science only as a purveyor of sensational discoveries.

The War, however, has shown millions of people in the Services and the war factories how important science can be. The very demands which are now being made for adequate food, housing and health are known to be based on scientific studies. The new standards can be achieved only by the application of science. Beyond that, we are beginning to see that not only these problems but also many political and social problems depend on science for their solution. With this realization we may hope will come an increasing emphasis on the balanced development of science, on its increasing use in satisfying social needs and on the spread into ordinary life of a scientific way of thinking and acting.

\section{ISLAND FLORA OF THE GULF OF GUINEA}

$T$ HE three Portuguese islands, S. Tomé, Principe and Annobon, which form the subject of this work* lie, together with Fernando Po, in the Gulf of Guinea. All are of comparatively recent volcanic origin and have a typical equatorial climate with considerable rainfall and very high humidity. Geological evidence and the insular character of their

* Catalogue of the Vascular Plants of S. Tomé (with Principe and Annobon). By Arthur Wallis Exell, and other members of the Department of Botany. Pp. xi +428 . (London: British Museum (Natural History), 1944.) $30 s$. 